\title{
Research of stakeholders' influence on STEM education implementation in professional training of engineering students \\ Grytsiuk 0.*
}

Kremenchuk Mykhailo Ostrohradskyi National University, Kremenchuk, Ukraine

Received: $05.10 .2019 \quad$ Accepted: 21.12.2019

\begin{abstract}
The paper analyzes career guidance and organizational aspects of the introduction of STEM education in the professional training of students of engineering specialties. It is shown that the United States of America, Australia, China, great Britain, Israel, Korea are the most actively promoting STEM approach in the educational direction, where thanks to the state and informal STEM education programs attract the attention of young people to STEM professions. Active application of STEM-approach in engineering education increases the competitiveness of graduates in the labor market. Today stakeholders or partners of educational institutions, public organizations, coalitions, institutions, business partners and sponsors, education centers, powerful technology companiesemployers, are of crucial importance. The paper presents a scheme of cooperation and partnership between stakeholders and the STEM education Department of the Institute of modernization of educational content, one of the priorities of which is the organization of career guidance projects for young people. The aim of STEM projects is to involve young people in high-tech STEM industry: neuroelectronics, robotics, bioelectronic medicine, neurobiology, application of the principles of integration and project approach in the educational process, which will improve the quality characteristics and efficiency of training students of engineering specialties and will meet the needs of stakeholders in the labor market.
\end{abstract}

Key words: STEM education, STEM education center, stakeholders, engineering education, integration principle.

\section{Дослідження впливу стейкхолдерів на впровадження STEM-освіти в професійну підготовку студентів інженерних спеціальностей}

\author{
Грицюк О. С. \\ Кременчуцький національний університет імені Михайла Остроградського, Кременчук, Україна
}

\begin{abstract}
Анотація. У статті проаналізовано профорієнтаційні й організаційні аспекти впровадження STEM-освіти в професійну підготовку студентів інженерних спеціальностей. Показано, що найбільш активно просувають STEM-підхід в освітньому напрямку Сполучені Штати Америки, Австралія, Китай, Великобританія, Ізраїль, Корея, де завдяки державним та несоормальним програмам STEM-освіти привертають увагу молоді до STEMпросресій. Активне застосування STEM-підходу в інженерній освіті підвищує конкурентоспроможність випускників на ринку праці, вирішальне значення на якому на сьогодні мають стейкхолдери, або партнери закладів освіти - громадські організації, коаліції, інституції, бізнес-партнери й спонсори, центри освіти, потужні технологічні компанії-роботодавці. У статті репрезентовано схему співпраці та партнерства стейкхолдерів і відділу STEM-освіти Інституту модернізації змісту освіти, одним з першочергових завдань якого є організація профрорієнтаційних проектів для молоді. Метою STEM-проектів є залучення молоді у наукомісткі STEM-галузі: нейроелектроніку, робототехніку, біоелектронну медицину, нейробіологію, застосування у навчальному процесі принципів інтеграції й проектного підходу, що підвищить якісні характеристики й ефективність навчання студентів інженерних спеціальностей і дозволить задовольнити запити стейхолдеров на ринку праці. Ключові слова: STEM-освіта, STEM-центр, стейкхолдери, інженерна освіта, принцип інтеграції.
\end{abstract}

\footnotetext{
Corresponding Author: Grytsiuk Olena Serhiivna.+38(05366)30050. E-mail: hrytsiuk.elena@gmail.com. Kremenchuk Mykhailo Ostrohradskyi National University,

Pershotravneva st, 20, Kremenchuk, Ukraine, 39600.

Відповідальний автор: Грицюк Олена Сергіївна. +38(05366)30050. E-mail: hrytsiuk.elena@gmail.com. Кременчуцький національний університет імені Михайла Остроградського, вул. Першотравнева, 20, м. Кременчук, Україна, 39600.
} 


\title{
Исследование влияния стейкхолдеров на внедрение STEM-образования в профессиональную подготовку студентов инженерных специальностей
}

\author{
Грицюк Е. С. \\ Кременчугский национальный университет имени Михаила Остроградского, Кременчуг, Украина
}

\begin{abstract}
Аннотация. В статье проанализированы профориентационные и организационные аспекты внедрения STEM-образования в профессиональную подготовку студентов инженерных специальностей. Показано, что наиболее активно продвигают STEM-подход в образовательном направлении Соединенные Штаты Америки, Австралия, Китай, Великобритания, Израиль, Корея, где благодаря государственным и неформальным программам STEM-образования привлекают внимание молодежи к STEM-профессиям. Активное применение STEM-подхода в инженерном образовании повышает конкурентоспособность выпускников на рынке труда, решающее значение на котором сегодня имеют стейкхолдеры, или партнеры учебных заведений общественные организации, коалиции, институты, бизнес-партнеры и спонсоры, центры образования, мощные технологические компании-работодатели. В статье представлена схема сотрудничества и партнерства стейкхолдеров и отдела STEM-образования Института модернизации содержания образования, одной из первоочередных задач которого является организация профориентационных проектов для молодежи. Целью STEM-проектов является привлечение молодежи в наукоемкие STEM-отрасли: нейроелектронику, робототехнику, биоэлектронные медицину, нейробиологию, применение в учебном процессе принципов интеграции и проектного подхода, что повысит качественные характеристики и эффективность обучения студентов инженерных специальностей и позволит удовлетворить запросы стейхолдеров на рынке труда .
\end{abstract}

Ключевые слова: STEM-образование, STEM-центр, стейкхолдеры, инженерное образование, принцип интеграции.

\section{Bcmyn}

Людство все більше наближається до четвертої промислової революції - часу, коли розробка нових матеріалів, прориви в галузі генної інженерії та цифрова трансформація будуть усе більше розмивати лінії між фізичним, біологічним і цифровим світом. Під час переходу до нового технологічного укладу протягом найближчих десятиліть у світі будуть формуватися зовсім нові великі ринки передових технологічних рішень і принципово нових продуктів і сервісів. Відповідно, четверта промислова революція буде вимагати незабаром, практично зараз, нової якості та кваліфікації кадрів і відповідної перепідготовки наявних фахівців. Тому сьогодні велика увага приділяється технічній (інженерній) освіті. Для збереження конкурентоспроможності України вкрай важливим $є$ впроваджувати інженерну освіту і одночасно посилювати професійну підготовку випускників. Для виконання даного завдання Міністерством освіти і науки України було прийнято рішення внести зміни в процес навчання у закладах освіти. Одним із способів підвищення інтересу студентів інженерних спеціальностей до навчання і наукової діяльності може стати активне впровадження STEM-освіти в 3 BO.

Акронім STEM (від англ. Science - природничі науки, Technology - технології, Engineering інжиніринг, проектування, дизайн, Mathematics - математика) позначає характерні риси відповідної дидактики, сутність якої виявляється у поєднанні міждисциплінарних практико орієнтованих підходів до вивчення природничо-математичних дисциплін [1]. Незважаючи на різноманіття наявних підходів, практично усі дослідники вважають, що STEM-освіта - це сучасний освітній феномен, який означає підвищення якості розуміння студентами дисциплін, що належать до науки, технології, інженерії та математики, мета якої - підготовка випускників до професійної діяльності, зокрема, розв'язання професійних завдань, вирішення проблем завдяки набуттю навичок наукового мислення і розвитку STEM-компетенцій протягом навчання.

У багатьох країнах STEM-освіта на сьогодні є пріоритетною. В Україні ця тенденція тільки починає отримувати поширення за підтримки Міністерства освіти і науки України, Інституту модернізації змісту освіти і провідних вітчизняних та зарубіжних компаній. Через багатогранність і складність явища необхідний певний час для вирішення проблем, пов'язаних з упровадженням навчальних програм в заклади освіти, а також зі створенням умов для реалізації STEM-проектів. 
Актуальні проблеми педагогічних досліджень в аспекті впровадження STEM-освіти в провідних країнах світу та перспектив її розвитку в Україні висвітлюються у розвідках О. Стрижака, І. Сліпухіної, Н. Полісун і І. Чернецького [1], С. Бабійчука [2], Д. Грузіна і Н. Новікової [3], Г. Сакунової і І. Мороза [4], Л. Мартін-Хансен (L. Martin-Hansen) [5]. Проблемам професійної підготовки та готовності до здобуття професії інженера присвячені праці А. Почтовюка, Д. Загірняка і К. Пряхіної [6], Г. Москалика, Л. Максимової і М. Мартиненко [7]. Питання організації навчання з елементами STEM-освіти для ефективного працевлаштування студентів інженерних спеціальностей розглядають як вітчизняні вчені (Т. Поясок, О. Беспарточна, О. Грицюк і Г. Сивякова [8], Т. Кірсанова [9], Н. Сергієнко [10], Т. Бирюкова, О. Олар, В. Федів і О. Микитюк [11], В. Харламенко [12]), так і зарубіжні дослідники й практики (М. Кім (M. Kim) і H. Кейхані (N. Keyhani) [13], А. Джамалудін (A. Jamaludin) і Д. Хунг (D. Hung) [14]). Окремі дослідження присвячені залученню до STEM-спеціальностей дівчат, їхній відповідній підготовці та проблемам, що виникають під час цих процесів (К. Менсфрілд (K.Mansfield), А. Велтон (A. Welton) і Гроган (M. Grogan) [15], М. Пелч (M. Pelch) [16]).

Отже, дослідження вчених, що займаються вивченням вищевказаних проблем, виявили низку суттєвих проблем і протиріч:

- наявна, традиційна (т.зв. знаннєва) система освіти не повною мірою відповідає вимогам і запитам навчання і підготовки робочої сили XXI століття з боку держави і провідних технологічних компаній, тобто присутні певні проблеми із системою навчання сучасних студентів науці, технології, інженерії та математики;

- дослідниками вказується на зниження мотивації під час вивчення STEM-предметів і вибору профресії такого типу; спостерігається надто низький рівень успішності у дисциплінах фізикоматематичного профілю, а також відсутність здібностей розв'язувати реальні проблеми, що потребують знань STEM-дисциплін і застосування практичних навичок.

Зазначені недоліки освіти можуть призвести до зниження кількості (нестачі) підготовлених кваліфікованих працівників у STEM-галузях. Така нестача наукових і технічних працівників $є$ й буде надалі загрозою для національної конкурентоспроможності. Все вищезазначене зумовило вибір теми статті.

Meта роботи: дослідити та проаналізувати ефективність впровадження STEM-освіти в Україні і провідних країнах світу для сприяння успішному працевлаштуванню та підвищення конкурентоспроможності студентів інженерних спеціальностей.

\section{II Матеріал і методи дослідження}

Для розв'язання поставлених завдань використано методи: теоретичний - для вивчення й аналізу науково-педагогічної літератури, навчальних програм, посібників, узагальнення інформації для визначення теоретико-методологічних основ дослідження; метод опису навчання за принципами STEM-освіти.

Сучасний етап розвитку світової освіти характеризується масовим впровадженням новітніх технологій у діяльність всіх учасників освітнього процесу.

Як зазначено у Національній стратегії розвитку освіти в Україні на період до 2021 року, освітня політика України спрямована на світовий ринок і формується з урахуванням інтеграційних процесів, зокрема виступає одним із напрямків руху України до Європи, одночасно наближуючи освітню систему України до європейських освітніх систем [17].

STEM - один 3 актуальних напрямів модернізації та інноваційного розвитку природничоматематичного й гуманітарного профрілів освіти України. Про це свідчить низка наказів Міністерства освіти і науки України, зокрема: № 708 від 17.05.2017 «Про проведення дослідно-експериментальної роботи всеукраїнського рівня за темою: «Науково-методичні засади створення та функціонування Всеукраїнського науково-методичного віртуального STEM-центру (BHMB STEM-центр)» на 20172021 роки»; № 628 від 24.04.2017 «Про внесення змін до складу робочої групи з питань впровадження STEM-освіти в Україні»; № 188 від 29.02.2016 «Про утворення робочої групи з питань впровадження STEM-освіти в Україні» [2].

2016 року на виконання наказу МОН № 188 у структурі Інституту модернізації змісту освіти створено відділ STEM-освіти, одним із завдань якого $€$ залучення закладів вищої освіти до 
удосконалення системи ранньої профрорієнтації молоді та її мотивації до вступу на природничі та інженерні спеціальності.

Отже, STEM-підхід протягом кількох років впроваджується в сучасну українську освіту як інноваційний метод, визнаний у всьому світі. Як зазначають Л. Самчук і Ю. Мойсеюк, важливу роль у сприянні інноваціям відіграє розбудова налагодженого партнерства закладу освіти 3 ключовими стейкхолдерами. Поняття «стейкхолдер» лише кілька років тому з'явилось в українському педагогічному і соціологічному дискурсі. Втім у західній практиці воно активно використовується з середини 90-х рр. XX ст., відображаючи ті особливості функціонування організацій, що забезпечують її життєдіяльність у нестабільному висококонкурентному зовнішньому середовищі та продуктивну взаємодію в межах внутрішнього. Найбільш відоме визначення цього поняття запропоновано відомим американським фрілософром і викладачем менеджменту в Школі Darden Університету Вірджинії Р. Едвардом Фріменом у монографії «Стратегічне управління: роль зацікавлених сторін», виданій у 1984 р., згідно з яким «стейкхолдер - це група (індивід), яка може впливати на досягнення організацією своїх цілей або на роботу організації в цілому» [18].

В Україні на сьогодні можна виокремити такі групи стейкхолдерів, зацікавлених у впровадженні STEM-освіти: громадські організації, коаліції, інституції, бізнес-партнери й спонсори закладів освіти, позашкільні заклади, центри освіти, потужні технологічні компанії тощо.

Взаємозв'язки між різними стейкхолдерами STEM-освіти та відповідним відділом Інституту модернізації змісту освіти (IM30) подано на рис. 1:

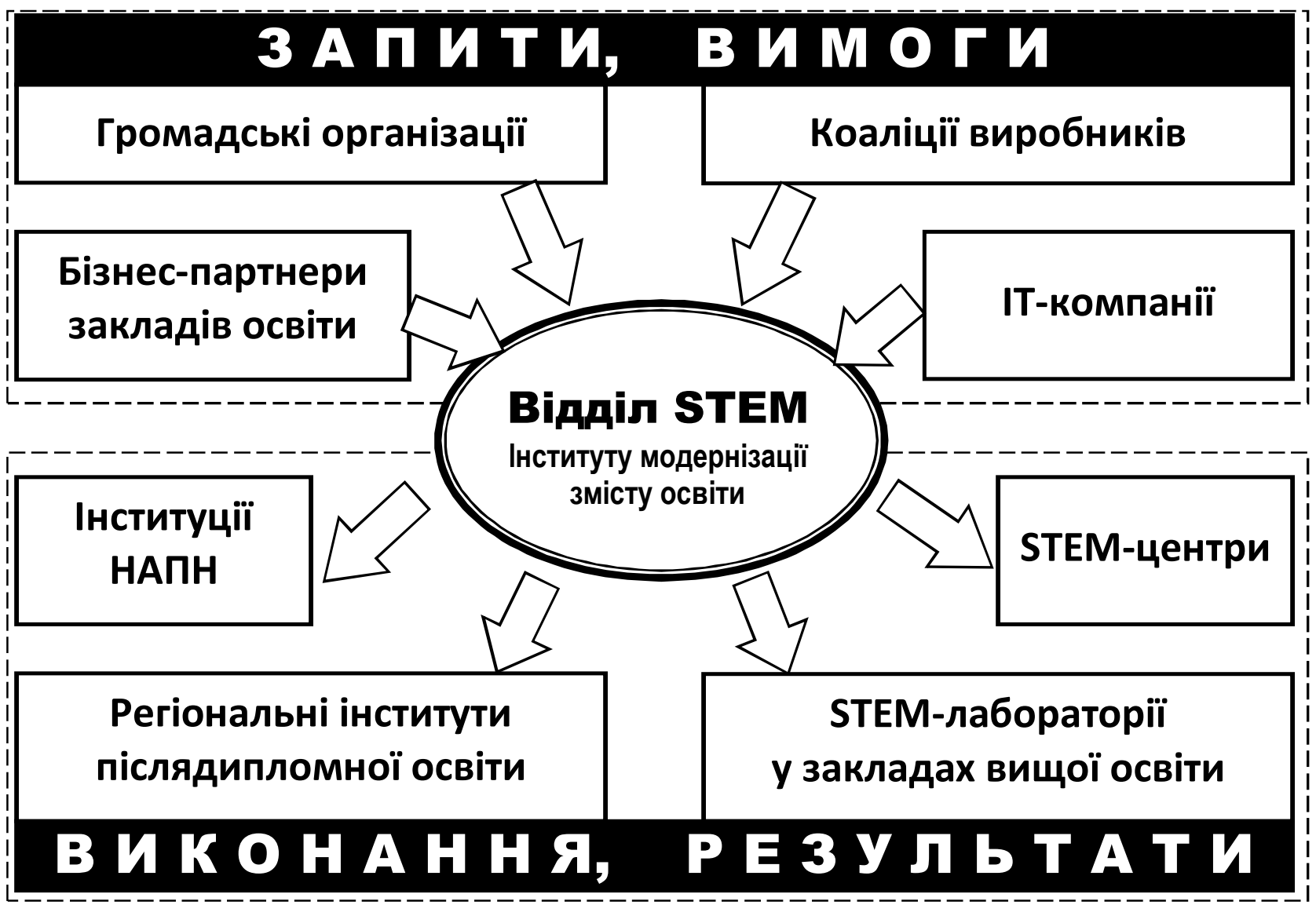

Рис. 1. Співпраця та партнерство стейкхолдерів і відділу STEM-освіти IM30

2015 року в Україні компаніями, навчальними закладами, асоціаціями, експертними організаціями, муніципалітетами та 3MI було укладено та підписано Меморандум про створення Коаліції STEM-освіти (STEM Education Coalition), в якому серед першочергових завдань друге місце посідає організація профорієнтаційних проектів для молоді. Серед організацій, що підписали Меморандум, такі відомі компанії-роботодавці, як «НАЕК Енергоатом», «Київстар», «Майкрософт Україна», Самсунг 
Електронікс», «Ericsson Україна». 3 іншого боку, у підписанні Меморандуму взяла участь низка українських закладів вищої освіти і навчальних центрів, зокрема, Київський університет культури та мистецтв, Національний технічний університет «ХПІ», Центр «Розвиток Корпоративної Соціальної Відповідальності» [19].

Організація профорієнтаційніх проектів для молоді, як відповідь на виклики нового часу, передбачає залучення молоді у наукомісткі STEM-галузі: нейроелектроніку, робототехніку, біоелектронну медицину, нейробіологію, математику, інженерію тощо. Виконання цього перспективного завдання дозволить підвищити якісні характеристики й ефективність використання людського капіталу, і, врешті-решт, задовольнити запити стейхолдеров на ринку праці.

Особливими рисами STEM-освіти, що розрізняють ї̈ з традиційним навчанням, $€$ активне застосування у навчальному процесі принципів інтеграції й проектного підходу.

Використання провідного принципу STEM-освіти - інтеграції - дає змогу здійснювати: модернізацію методологічних засад, змісту, обсягу навчального матеріалу предметів природничоматематичного циклу технологізацію процесу навчання та формування навчальних компетентностей якісно нового рівня якіснішу підготовку молоді до успішного працевлаштування та подальшої освіти [9].

STEM-освіту часто називають «навчанням навпаки», «перевернутою освітою» тому, що шлях «від теорії до практики» у STEM зазвичай зворотний: спочатку практика (придумування та конструювання пристроїв і механізмів), а вже потім, у процесі цієї діяльності, - опанування теорії і нових знань [20].

\section{III Результати}

Освіта в галузі STEM $€$ основою підготовки робітників в області високих технологій. Тому багато країн, такі як Австралія, Китай, Великобританія, Ізраїль, Корея, США проводять державні програми в галузі STEM-освіти. У Франції, Японії, Південній Африці навчальні заклади та різні професійні організації займаються розробкою неформальних програм STEM-освіти (наприклад, літні табори, позашкільні заходи, конкурси тощо), які привертають увагу молоді до STEM-професій і дають можливість для навчання за різними творчими та інтелектуальними напрямками [3].

Найбільш активно просувають STEM-підхід в освітньому напрямку Сполучені Штати Америки. Програма STEM впроваджується на державному рівні. Такий підхід запроваджено у багатьох провідних університетах США (Орегонський державний університет - 169 STEM-спеціальностей, Університет Джерджа Мейсона - 82, Колорадський університет - 50, Сент-Луїський університет - 47). Зокрема, у провідних навчальних закладах з упровадженням STEM-освіти поряд із вивченням STEM-дисциплін особливу увагу приділяють охороні довкілля. У коледжі Св. Олафа (штат Міннесота) вимагають, щоб кожний студент вивчав щонайменше два курси з дисциплін STEM. А у лабораторії нанотехнологій Каліфорнійського університету в Сан-Дієго у складі дослідницької групи працюють студенти з Білорусі, Таїланду й Мексики. Вони проводять дослідження в галузі сонячної енергетики, зокрема, розробляють більш дешеві й міцні панелі сонячних батарей. В США у 2013 році було введено новий трьохкомпонентний стандарт природничо-наукової освіти: Practices - наукові та інженерні навички, Content - основні предметні знання, Crosscutting concepts - узагальнюючі (наскрізні) уміння [20].

Один із підходів до формування та зміцнення професійних кадрів, що грамотно розуміють STEM, - це вивчення підходів для посилення викладання курсів STEM на рівні закладу освіти. Адміністрації інженерних інститутів за підтримки своїх факультетів створюють центри, присвячені просуванню досконалості в інженерній підготовці. Ці центри сприяють професійному розвитку викладачів, щоб вони вміли належним чином викладати та навчати STEM-дисциплінам на інженерних факультетах. Окрім того, агентство США з акредитації інженерних програм (АВЕТ) пов'язує співпрацю 3 інженерною навчальною програмою завдяки двом із семи обов'язкових результатів навчання студентів. Два результати, безпосередньо стосуються здатності студента до співпраці, тобто «здатності ефективно працювати в команді» та «здатності ефективно спілкуватися». Роботодавці також бажають, щоб випускники уміли співпрацювати в командах, але зазначають, що студенти-інженери до цього ще не достатньо підготовлені [21].

Інженерна галузь все частіше розуміється як шлях до навчання протягом усього життя, а не як подія, що відбувається лише в умовах університету. Національна інженерна академія (США) у програмі «Інженер 2020 року: погляд на інженерну діяльність у новому столітті» та АВЕТ, орган США 3 
акредитації інженерних програм, разом визначили широкий спектр якостей та здібностей, життєво важливих для майбутніх інженерів нової епохи. Визначені якості містять здатність займатися самонавчанням протягом усього життя, творчо функціонувати, працювати в різних дисциплінах, практичну винахідливість та, крім підтримки технічної експертизи в інженерних галузях, ще здатність спілкуватися з широкою аудиторією клієнтів. Ці якості важливі для широкого кола практичної інженерної діяльності й засвоюються в них [22].

Працівникам інженерних галузей доволі часто в своїй діяльності доводиться займатися науковою роботою й навіть експериментальними дослідженнями. Отже, сучасний інженер - це передусім учений.

Сьогодні вченим потрібно не лише бути креативними, винахідливими щодо своїх дослідницьких питань та розуміти їхні польові та дослідницькі методи, а й бути здатними робити набагато іншого. Це, безумовно, не відповідає інтересам, завданням та здібностям кожного вченого, і багато вчених часто скаржаться на занадто багато обов'язків, що відводять їх від «реальних досліджень», а деякі мають досить вузько визначені обов'язки. Часто у багатьох не вчених все ще існує думка, що вчені - це люди, схожі на Ейнштейна в білих халатах, які маніакально працюють з барвистими хімічними речовинами. Звичайно, хоча це все ще поширене зображення в 3MI, це значною мірою не відповідає дійсності (i давно не відповідає дійсності). У сучасній науці, зазвичай, учені повинні бути більш ніж відмінними дослідниками, працюючи самостійно у своїх лабораторіях. Вони мають вміти співпрацювати, часто навіть у різних дисциплінах; їм потрібно донести свої ідеї та висновки до різних зацікавлених сторін, які приймають рішення про їх фрінансування; і їм потрібно навчити наступне покоління наслідувати їх знання і навички. Тож кар'єрні профілі вчених значно розширилися протягом десятиліть. Їм потрібно не лише бути творчими, розуміти їхні галузі та методи дослідження, вони також мають знати, як навчати, як каталогізувати, як заповнювати форми пропозицій, як подати свої результати для різних аудиторій, як співпрацювати з колегами зі всього світу та ін. Сучасні наукові галузі, які існують сьогодні, i, мабуть, будуть у майбутньому, зазвичай вимагають від учених мати різноманітні компетенції та інтереси. Отже, протягом навчання майбутніх вчених надзвичайно важливо виходити за рамки простого знання, й одночасно шукати та розвивати додаткові навички, риси та інтереси, необхідні хорошим або навіть відмінним вченим [23].

Г. Сакунова та І. Мороз, досліджуючи зарубіжний досвід STEM-освіти, зауважують, що провідні країни світу ведуть активну діяльність із залучення шкіл, ЗВО та підприємств до інтеграції STEM в освіту і науку та, у подальшому, працевлаштування STEM-спеціалістів в усі області ринку праці [4].

На державному рівні STEM-процеси створюють необхідні умови для реалізації права громадян України на отримання якісної, затребуваної на ринку праці, освіти, забезпечують інноваційність розвитку й ефективність системи освіти в умовах децентралізації її управління, прискорюють інтеграцію нашої держави у світовий економіко-освітній простір, підвищують національну безпеку і добробут українського суспільства. значущими соціальними наслідками впровадження STEM-освіти $€$ формування у підростаючого покоління раннього професійного вибору, усвідомлення його значущості на особистісному і суспільному рівні, популяризація інноваційної інженерної діяльності, підтримка обдарованої молоді, генерування, розвиток і поширення інноваційних педагогічних технологій [1].

\section{IV Обговорення}

Л. Мартін-Хансен зазначає, що вища освіта має значення у формуванні позитивної ідентичності в галузі STEM, оскільки активний набір вступників на спеціальності, пов'язані з наукою, технікою, інженерією та математикою, викликає ідентичність STEM-студента - особистість протягом навчання вже починає сприймати себе майбутнім математиком, вченим, інженером, програмістом. Завдяки формуванню такої позитивної ідентичності згодом підвищується й прогноз щодо майбутнього побудування кар'єри в галузі STEM [5].

Д. Карлайл і Г. Вівер дотримуються думки, що важливе значення для удосконалення підготовки інженерів мають центри STEM-освіти (SEC). На погляд дослідників, вони інформують студентів щодо переваг STEM-освіти та уніфікують зусилля закладів вищої освіти, підвищуючи їхню вагомість та важливість як внутрішньо, так і зовні. Вони забезпечують фінансування STEM-програм, що надає додаткові ресурси та стимули для впровадження STEM-освіти завдяки збільшенню кількості годин навчальних практик (EBIPS) та науково-дослідних проектів STEM. STEM-центри доповнюють цю 
діяльність оцінюванням результатів навчання та навчальними інноваціями. На сьогодні поширюється відкриття центрів STEM-освіти (SEC) у багатьох закладах вищої освіти США. Отже, значна увага, яка приділяється STEM-освіті на національному рівні, посилила залучення університетів та коледжів до реформи освіти у напрямку STEM [24].

М. Теккумру-Кайза і М. Штайн, досліджуючи наукову й математичну складові інженерної освіти, наголошують на підвищенні рівня готовності вступників до навчання на інженерних спеціальностях й початку кар'єри та рівня професійної підготовки фахівців. Водночас, вчені зазначають, що розробники освітньої політики та досвідчені працівники визнають необхідність серйозного удосконалення навчальних практик за усіма предметами STEM, особливо у сфері науки і математики. У США загальні основні державні стандарти математики та наукові стандарти нового покоління почали надавати уявлення про те, як має виглядати високоякісна навчальна програма з математики та науки, проте, на жаль, це бачення кардинально відходить від змісту звичайної практики у закладах освіти [25].

На думку Н.Сергієнко, якщо раніше випускники вищих навчальних закладів мали вузько направлену спеціалізацію, то сьогодні ринок праці диктує інші умови. У світлі розвитку технологій, автоматизації виробництва та повсякденного життя затребуваними стають спеціалісти, здатні до інтеграції, комунікації, командної роботи, вони повинні мати уявлення про новітні тенденції в науці і техніці, бути впевненими у своїх силах, вміти застосовувати науково-технічні знання у реальному житті. Всім цім вимогам відповідає STEM-освіта. Програма впровадження в начальний процес STEM-освіти дозволить підготувати студентів до успішного працевлаштування [10].

Т. Бирюкова, О. Олар, В. Федів і О. Микитюк наводять приклад того, як STEM-освіта впливає на професійну орієнтацію студентів за обраною спеціальністю. Дослідники зазначають, що на занятті зі STEM-технологіями студенти демонструють презентації і коментують їх, при цьому набувають вміння представляти свої роботи, пов'язують свої дослідження з життям, проявляють самостійність, цілеспрямованість, наполегливість в отриманні рішення поставленої задачі. Завдяки цьому реалізуються і принципи STEM-освіти, що об'єднують міждисциплінарний та проектний підходи, основою яких $є$ інтеграція природничих наук у технології, інженерну майстерність та математику. Створюючи свої доповіді на базі проведених досліджень, студенти закладають зародки майбутніх професійних компетентностей. Таким чином, навчальний процес стає наближеним до реальних різноманітних напрямків науково-дослідницької та професійної діяльності [11].

В. Харламенко, аналізуючи стан сучасного ринку праці й враховуючи його динаміку, доходить висновку, що в основі професій майбутнього будуть технології, пов'язані з STEM-освітою. Дослідниця зазначає, що підготовка представника професій майбутнього вимагає формування в нього знань про сучасний ринок праці, технології вибору професії, пов'язані із STEM [12].

\section{V Висновки}

Сучасна інженерна освіта передбачає реалізацію нових підходів до навчання, заснованих на актуальному змісті освіти, що задовольняє вимоги стейхолдерів - партнерів освіти, зацікавлених, передусім, у результатах професійної підготовки випускників. Одним з таких підходів є STEM-освіта.

Актуалізація змісту можлива за умов вивчення фундаментальних наукових дисциплін, що базуються на сучасних, практично значущих прикладах і завданнях.

Методи, форми і засоби, які використовуються під час навчання студентів інженерних спеціальностей, мають бути пов'язані з новими науковими й практичними розробками, що дозволяє на практиці показати ефективність STEM-технологій і підвищити професійну спрямованість навчання та мотивацію випускників щодо вибору профресій у STEM-галузі.

\section{Бібліографрічні посилання}

1. Стрижак О. Є., Сліпухіна І. А., Полісун Н. І., Чернецький І. С. STEM-освіта: основні деффініції. Інформаційні технології $і$ засоби навчання. 2017. Т. 62, № 6. С. 16-33.

2. Бабійчук C. STEM-освіта у США: проблеми та перспективи. Педагогічний часопис Волині. 2018. № 1(8). С. $12-17$.

3. Грузін Д. В., Новікова Н. В. Актуальність застосування STEM-технологій в навчальному процесі. Сучасні інформаційні технології та інноваційні методики навчання: досвід, тенденції, перспективи: матеріали I Всеукраїнської науково- 
практичної Інтернет-конфреренції 3 міжнародною участю (Тернопіль, 9-10 лист. 2017 р.). C. 30-34. URL: http://conf.fizmat.tnpu.edu.ua/media/magazin/2017/09.11.2017.pdf. (дата звернення: 21.08.2019).

4. Сакунова Г., Мороз І. STEM-освіта: зарубіжний досвід та перспективи розвитку в Україні. Наукові записки ЦДПУ. Серія: Педагогічні науки. 2018. Вип. 168. С. 204-208.

5. Martin-Hansen L. Examining ways to meaningfully support students in STEM. International Journal of STEM Education. 2018. Vol. 5, Iss. 1. URL: https://stemeducationjournal.springeropen.com/track/pdf/10.1186/s40594-018-0150-3. (дата звернення: 27.08.2019). DOI: https://doi.org/10.1186/s40594-018-0150-3

6. Pochtovyuk A., Zagirniak D., Pryakhina K. The Problems of Training of Highly Skilled Engineers in Ukraine in the Context of International Tendencies. IEEE Proceedings of the International Conference on Modern Electrical and Energy Systems MEES 2017 (Kremenchuk, Ukraine, 15-17 November 2017). Kremenchuk, 2018. P. 340-343.

7. Moskalyk H., Maksymova L., Martynenko M. Philosophical Principles of Formation of Secondary-School Students' Readiness for Getting a Profession of an Engineer. IEEE Proceedings of the International Conference on Modern Electrical and Energy Systems - MEES 2017 (Kremenchuk, Ukraine, 15-17 November 2017). Kremenchuk, 2018. P. 348-351.

8. Poyasok T., Bespartochna O., Grytsiuk O., Sivyakova G. On the Expediency of Introducing the "Mathematics - Theoretical Foundations of Electrical Engineering" Integrated Course into the Educational Process. IEEE Proceedings of the International Conference on Modern Electrical and Energy Systems - MEES 2017 (Kremenchuk, Ukraine, 15-17 November 2017). Kremenchuk, 2018. P. 332-335.

9. Кірсанова T. М. STEM-освіта: впровадження та перспективи розвитку. URL: https://vseosvita.ua/library/pedagogicna-radastem-osvita-vprovadzenna-ta-perspektivi-rozvitku-76763.html. (дата звернення: 23.08.2019).

10. Сергієнко H. В. STEM-освіта - нові можливості для сучасного викладача та студента. STEM-освіта - проблеми та перспективи: збірник матеріалів II Міжнародного науково-практичного семінару (Кропивницький, 25-26 жовтня 2017 р.). Кропивницький: КЛА НАУ, 2017. С. 90-91.

11. Бирюкова Т., Олар О., Федів В., Микитюк О. Використання елементів stem-освіти у підготовці студента-медика. Матеріали VII Міжнародної науково-практичної онлайн-інтернет конференції (Кропивницький, 1-15 лист. 2018 р.). URL: https://www.cuspu.edu.ua/ua/vii-mizhnarodna-naukovo-praktychna-onlain-internet-konferentsiia-problemy-ta-innovatsiyiv-pryrodnycho-matematychniy-tekhnolohichniy-i-profesiyniy-osviti-2018-rik/sektsiia-2-innovatsii-v-osviti-metodolohichniteoretychni-praktychni-ta-metodychni-aspekty/8515-vykorystannya-elementiv-stem-osvity-u-pidhotovtsi-studenta-medyka. (дата звернення: 23.08.2019).

12. Харламенко B. STEM-освіта: профорієнтологічний аспект. STEM-освіта: стан впровадження та перспективи розвитку: матеріали III Міжнародної науково-практичної конференції (Київ, 9-10 лист. 2017 р.), К.: ДНУ «Інститут модернізації змісту освіти», 2017. С. 132-135.

13. Kim M. S., Keyhani N. Understanding STEM teacher learning in an informal setting: a case study of a novice STEM teacher. Research and Practice in Technology Enhanced Learning. 2019. Vol. 14, Iss.9. URL: https://telrp.springeropen.com/track/pdf/10.1186/s41039-019-0103-6. (дата звернення: 30.08.2019).

14. Jamaludin A., Hung D. Problem-solving for STEM learning: navigating games as narrativized problem spaces for $21^{\text {st }}$ century competencies. Research and Practice in Technology Enhanced Learning. 2016. Vol. 12, Iss. 1. URL: https://telrp.springeropen.com/track/pdf/10.1186/s41039-016-0038-0. (дата звернення: 30.08.2019).

15. Mansfield K. C., Welton A. D., Grogan M. "Truth or consequences": a feminist critical policy analysis of the STEM crisis. International Journal of Qualitative Studies in Education. 2014. Vol. 27, Iss. 9, P. 1155-1182.

16. Pelch M. Gendered differences in academic emotions and their implications for student success in STEM. International Journal of STEM Education. 2018. Vol. 5, Iss. 1. URL: https://stemeducationjournal.springeropen.com/track/pdf/10.1186/s40594-0180130-7. (дата звернення: 02.09.2019). DOI: https://doi.org/10.1186/s40594-018-0130-7

17. Національна стратегія розвитку освіти в Україні на період до 2021 року: затв. Указом Президента України від 25.06.2013 № 344/2013. URL: http://oneu.edu.ua/wp-content/uploads/2017/11/nsro_1221.pdf. (дата звернення: 22.08.2019).

18. Самчук Л., Мойсеюк Ю. Стейкхолдери освіти (рекомендаційний бібліографічний список). Аналітичний вісник у ссрері освіти й науки: довідковий бюлетень. 2018. Вип. VIII. C. 15-28. URL: http://lib.iitta.gov.ua/712161/1/Analituchnuy_visnuk_2018-8.pdf. (дата звернення: 27.08.2019).

19. Меморандум про створення Коаліції STEM-освіти. URL: http://csr-ua.info/csr-ukraine/wpcontent/uploads/2016/01/STEM_memorandum_FINAL_A11.pdf. (дата звернення: 27.08.2019).

20. Теоретичні аспекти інноваційної моделі STEM-освіти. URL: https://naurok.com.ua/teoretichni-aspekti-innovaciyno-modelistem-osviti-78197.html. (дата звернення: 21.08.2019).

21. Tinnell T., Ralston P., Tretter T., Mills M. Sustaining pedagogical change via faculty learning community. International Journal of STEM Education. 2019. Vol. 6, Iss. $1 . \quad$ URL: https://stemeducationjournal.springeropen.com/track/pdf/10.1186/s40594-019-0180-5. (дата звернення: 03.09.2019). DOI: https://doi.org/10.1186/s40594-019-0180-5

22. Foster Ch., Wigner A., Lande M., Jordan S. Learning from the parallel pathways of Makers to broaden pathways to engineering. International Journal of STEM Education. 2018. Vol. 5, Iss. 1. URL: https://stemeducationjournal.springeropen.com/track/pdf/10.1186/s40594-017-0098-8. (дата звернення: 03.09.2019). DOI: 10.1186/s40594-017-0098-8

23. Höffler T., Köhler C., Parchmann I. Scientists of the future: an analysis of talented students' interests. International Journal of STEM Education. 2019. Vol. 6, Iss. 1. URL: https://stemeducationjournal.springeropen.com/track/pdf/10.1186/s40594-0190184-1. (дата звернення: 04.09.2019). DOI: https://doi.org/10.1186/s40594-019-0184-1 
24. Carlisle D., Weaver G. STEM education centers: catalyzing the improvement of undergraduate STEM education. International Journal of STEM Education. 2018. Vol. 5, Iss. $1 . \quad$ URL: https://stemeducationjournal.springeropen.com/track/pdf/10.1186/s40594-018-0143-2. (дата звернення: 05.09.2019). DOI: https://doi.org/10.1186/s40594-018-0143-2

25. Tekkumru-Kisa M., Stein M. Designing, facilitating, and scaling-up video-based professional development: supporting complex forms of teaching in science and mathematics. International Journal of STEM Education. 2017. Vol. 4, Iss. 1. URL: https://stemeducationjournal.springeropen.com/track/pdf/10.1186/s40594-017-0087-у. (дата звернення: 06.09.2019). DOI: 10.1186/s40594-017-0087-y

\section{References}

1. Ctryzhak, O. Ye., Slipukhina, I. A., Polisun, N. I. \& Chernets'kyy, I. S. (2017). STEM-osvita: osnovni definitsiyi, Information Technologies and Learning Tools, 62(6), 16-33.

2. Babiychuk, S. (2018). STEM-osvita u SSHA: problemy ta perspektyvy, Pedahohichnyy chasopys Volyni, 1(8), 12-17.

3. Hruzin, D. V., Novikova, N. V. (2017). Aktual'nist' zastosuvannya STEM-tekhnolohiy v navchal'nomu protsesi, Suchasni informatsiyni tekhnolohiyi ta innovatsiyni metodyky navchannya: dosvid, tendentsiyi, perspektyvy: materialy I Vseukrayins'koyi naukovo-praktychnoyi Internet-konferentsiyi z mizhnarodnoyu uchastyu (Ternopil', 9-10 lyst. 2017 r.), 30-34. URL: http://conf.fizmat.tnpu.edu.ua/media/magazin/2017/09.11.2017.pdf. (accessed: 21.08.2019).

4. Sakunova, H., Moroz, I. (2018). STEM-osvita: zarubizhnyy dosvid ta perspektyvy rozvytku v Ukrayini, Naukovi zapysky TSDPU. Seriya: Pedahohichni nauky, 168, 204-208.

5. Martin-Hansen, L. (2018). Examining ways to meaningfully support students in STEM. International Journal of STEM Education, 5(1). URL: https://stemeducationjournal.springeropen.com/track/pdf/10.1186/s40594-018-0150-3. (accessed: 27.08.2019). DOI: https://doi.org/10.1186/s40594-018-0150-3

6. Pochtovyuk, A., Zagirniak, D., Pryakhina, K. (2018). The Problems of Training of Highly Skilled Engineers in Ukraine in the Context of International Tendencies, IEEE Proceedings of the International Conference on Modern Electrical and Energy Systems - MEES 2017 (Kremenchuk, Ukraine, 15-17 November 2017), 340-343.

7. Moskalyk, H., Maksymova, L., Martynenko, M. (2018). Philosophical Principles of Formation of Secondary-School Students' Readiness for Getting a Profession of an Engineer, IEEE Proceedings of the International Conference on Modern Electrical and Energy Systems - MEES 2017 (Kremenchuk, Ukraine, 15-17 November 2017), 348-351.

8. Poyasok, T., Bespartochna, O., Grytsiuk, O. \& Sivyakova, G. (2018). On the Expediency of Introducing the "Mathematics Theoretical Foundations of Electrical Engineering" Integrated Course into the Educational Process, IEEE Proceedings of the International Conference on Modern Electrical and Energy Systems - MEES 2017 (Kremenchuk, Ukraine, 15-17 November 2017), 332-335.

9. Kirsanova, T. M. (2018). STEM-osvita: vprovadzhennya ta perspektyvy rozvytku. URL: https://vseosvita.ua/library/pedagogicnarada-stem-osvita-vprovadzenna-ta-perspektivi-rozvitku-76763.html. (accessed: 23.08.2019).

10. Serhiyenko, N. V. (2017). STEM-osvita - novi mozhlyvosti dlya suchasnoho vykladacha ta studenta, STEM-osvita - problemy ta perspektyvy: zbirnyk materialiv II Mizhnarodnoho naukovo-praktychnoho seminaru (Kropyvnyts'kyy, 25-26 zhovtnya 2017 r.), 90-91.

11. Byryukova, T., Olar, O., Fediv, V. \& Mykytyuk, O. (2018). Vykorystannya elementiv stem-osvity u pidhotovtsi studenta-medyka. Materialy VII Mizhnarodnoyi naukovo-praktychnoyi onlayn-internet konferentsiyi (Kropyvnyts'kyy, 1-15 lyst. 2018 r.). URL: https://www.cuspu.edu.ua/ua/vii-mizhnarodna-naukovo-praktychna-onlain-internet-konferentsiia-problemy-ta-innovatsiyi-vpryrodnycho-matematychniy-tekhnolohichniy-i-profesiyniy-osviti-2018-rik/sektsiia-2-innovatsii-v-osviti-metodolohichniteoretychni-praktychni-ta-metodychni-aspekty/8515-vykorystannya-elementiv-stem-osvity-u-pidhotovtsi-studenta-medyka. (accessed: 23.08.2019).

12. Kharlamenko, V. (2017). STEM-osvita: proforiyentolohichnyy aspekt, STEM-osvita: stan vprovadzhennya ta perspektyvy rozvytku: materialy III Mizhnarodnoyi naukovo-praktychnoyi konferentsiyi (Kyyiv, 9-10 lyst. 2017 r.), 132-135.

13. Kim, M. S., Keyhani, N. (2019). Understanding STEM teacher learning in an informal setting: a case study of a novice STEM teacher, Research and Practice in Technology Enhanced Learning, 14(9). URL: https://telrp.springeropen.com/track/pdf/10.1186/s41039-019-0103-6. (accessed: 30.08.2019).

14. Jamaludin, A., Hung, D. (2016). Problem-solving for STEM learning: navigating games as narrativized problem spaces for $21^{\text {st }}$ century competencies, Research and Practice in Technology Enhanced Learning, 12(1). URL: https://telrp.springeropen.com/track/pdf/10.1186/s41039-016-0038-0. (accessed: 30.08.2019).

15. Mansfield, K. C., Welton, A. D., \& Grogan, M. (2014). "Truth or consequences": a feminist critical policy analysis of the STEM crisis, International Journal of Qualitative Studies in Education, 27(9), 1155-1182.

16. Pelch, M. (2018). Gendered differences in academic emotions and their implications for student success in STEM, International Journal of STEM Education, 5. URL: https://stemeducationjournal.springeropen.com/track/pdf/10.1186/s40594-018-0130-7. (accessed: 02.09.2019). DOl: https://doi.org/10.1186/s40594-018-0130-7

17. Natsional'na stratehiya rozvytku osvity v Ukrayini na period do 2021 roku (2013). URL: http://oneu.edu.ua/wpcontent/uploads/2017/11/nsro_1221.pdf. (accessed: 22.08.2019).

18. Samchuk, L., Moyseyuk, Yu. (2018). Steykkholdery osvity (rekomendatsiynyy bibliohrafichnyy spysok), Analitychnyy visnyk u sferi osvity y nauky: dovidkovyy byuleten', VIII, 15-28. URL: http://lib.iitta.gov.ua/712161/1/Analituchnuy_visnuk_2018-8.pdf. (accessed: 27.08.2019). 
19. Memorandum pro stvorennya Koalitsiyi STEM-osvity. (2016). URL: http://csr-ua.info/csr-ukraine/wpcontent/uploads/2016/01/STEM_memorandum_FINAL_A11.pdf. (accessed: 27.08.2019).

20. Teoretychni aspekty innovatsiynoyi modeli STEM-osvity. (2018). URL: https://naurok.com.ua/teoretichni-aspekti-innovaciynomodeli-stem-osviti-78197.html. (accessed: 21.08.2019).

21. Tinnell, T., Ralston, P., Tretter, T. \& Mills, M. (2019). Sustaining pedagogical change via faculty learning community, International Journal of STEM Education, 6. URL: https://stemeducationjournal.springeropen.com/track/pdf/10.1186/s40594-019-0180-5. (accessed: 03.09.2019). DOI: https://doi.org/10.1186/s40594-019-0180-5

22. Foster, Ch., Wigner, A., Lande, M., Jordan, S. (2018). Learning from the parallel pathways of Makers to broaden pathways to engineering, International Journal of STEM Education, $5 . \quad$ URL: https://stemeducationjournal.springeropen.com/track/pdf/10.1186/s40594-017-0098-8. (accessed: 03.09 .2019 ). DOI: 10.1186/s40594-017-0098-8

23. Höffler, T., Köhler, C., Parchmann, I. (2019). Scientists of the future: an analysis of talented students' interests, International Journal of STEM Education, 6. URL: https://stemeducationjournal.springeropen.com/track/pdf/10.1186/s40594-019-0184-1. (accessed: 04.09.2019). DOI: https://doi.org/10.1186/s40594-019-0184-1

24. Carlisle, D., Weaver, G. (2018). STEM education centers: catalyzing the improvement of undergraduate STEM education, International Journal of STEM Education, 5. URL: https://stemeducationjournal.springeropen.com/track/pdf/10.1186/s40594-018-0143-2. (accessed: $\quad 05.09 .2019$ ). DOI: https://doi.org/10.1186/s40594-018-0143-2

25. Tekkumru-Kisa, M., Stein, M. (2017). Designing, facilitating, and scaling-up video-based professional development: supporting complex forms of teaching in science and mathematics, International Journal of STEM Education, 4. URL: https://stemeducationjournal.springeropen.com/track/pdf/10.1186/s40594-017-0087-y. (accessed: $\quad 06.09 .2019$ ). DOI: 10.1186/s40594-017-0087-y

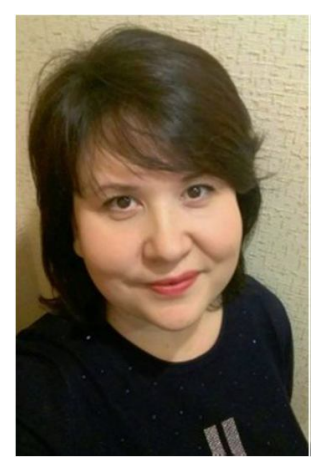

\section{Грицюк Олена Сергіївна,}

кандидат педагогічних наук, доцент, доцент кафедри інформатики і вищої математики,

Кременчуцький національний університет імені Михайла Остроградського,

адреса. вул. Першотравнева, 20, м. Кременчук, Україна, 39600

Тел. (05366) 3-00-50. E-mail: hrytsiuk.elena@gmail.com

\section{Grytsiuk Olena Serhiivna,}

PhD (Ped.), Associated Professor, Associated Professor of Mathematics and Computer Science Department Kremenchuk Mykhailo Ostrohradskyi National University,

Pershotravneva st, 20, Kremenchuk, Ukraine, 39600

Tel. +38(05366) 30050. E-mail: hrytsiuk.elena@gmail.com

ORCID: http://orcid.org/0000-0003-2117-626X

\section{Citation (APA):}

Grytsiuk, O. (2019). Research of stakeholders' influence on STEM education implementation in professional training of engineering students. Engineering and Educational Technologies, 7 (4), 57-66. doi: https://doi.org/10.30929/2307-9770.2019.07.04.05

\section{Цитування (ДСТУ 8302:2015):}

Грицюк О. С. Дослідження впливу стейкхолдерів на впровадження STEM-освіти в профресійну підготовку студентів інженерних спеціальностей / Інженерні та освітні технології. 2019. Т. 7. № 4. С. 57-66. doi: https://doi.org/10.30929/2307-9770.2019.07.04.05

Обсяг статmі: сторінок - 10 ; умовних друк. аркушів - 1,448. 